\title{
A Woman's Journey in the BPP and BLA: Safiya Bukhari, 1950—2003
}

Safiya Bukhari

The following interview was conducted in New York City on September 27, 1992 for International Women's Day 1995.

From: Assata Shakur Forum

ATS-L Archives.

Wednesday, March 1995: ats@etext.org

Q: The first question I have is, how did you get involved with the Black Panther Party (BPP)?

I was going to college to be a doctor. The first year in college I was just into my studies. But it was right here in Brooklyn, actually, in New York City College, and the people on campus thought that I was stuck up because I didn't associate-I was studying a lot. And so the second year, in order to break that mode, I pledged for a sorority called Hamilton House. That same year the sorority became integrated. We elected the first Black president. And one of the projects of the sorority was to adopt under-privileged children in foreign countries. Our President that year said we didn't have to go any further than the United States to find under-privileged children. A lot of people didn't believe that there were hungry children that needed to be fed right here in the US, even in New York.

So three of us were assigned to go investigate the situation and we ended up going to Harlem to see if there really were hungry children. It was Yvonne Smallwood, Wanda Davis and myself. And the first people we ran into when we got there were the Panthers. Wanda got totally involved from the beginning; she fell in love with a Panther and joined the Party and everything. I didn't go that route. I simply didn't believe the things that the Panthers were saying.

About the hungry children: we went back and reported that the result was that there were a lot of people who were eating out of garbage cans, that there were indecent conditions that they were living in, etc. The next question was what to do about it? Should we start our own program or should we get involved in the things that already went on - because the Panthers already had the Free Breakfast Program. So, in essence we elected to just assign various members of our sorority to work with the free Breakfast Program. We would collect the food, we cooked the food, we would help the children with their homework, things like that, but I still didn't believe in what the 
Panthers were saying. I didn't think that the violence was happening. I didn't think that the conspiracies were going on. I didn't believe that the police were doing what they said they were doing, etc.

Two incidents happened that made me start to think seriously about what the ideology of the Party was and take the rhetoric of the Party seriously. With the Breakfast Program, the police started putting our rumours. The children stopped coming to the breakfast program. And I wondered why - so I found out from talking to some of the parents that the police kept telling them that we were feeding the children poisoned food-so they were stopped from bringing their children to the program and that made me angry. I mean, we were getting up at outrageous hours in the morning to take care of this before going to school-I was still going to school fulltime- - I was cooking the food and we were eating it right along with the children. They didn't have a breakfast program in the schools themselves, they were not making an effort to feed the children, but they didn't want us to feed the children. And I was incensed about that.

Then, myself and my friend Wanda were walking on 42nd Street-I still hadn't joined the Party, that still didn't make me angry enough to join the Party - well, there we were on 42nd Street one day and going to Times Square we saw this big crowd on the corner and so we went rushing to see what was going on. A Panther was on the corner selling papers and the police were harassing him. So, believing whole-heartedly in the Constitution, I asked him what he was doing. And the police said if I didn't stop that they were going to arrest me, too. I said he had a constitutional right to sell the papers; actually, I said he had a constitutional right to disseminate political literature, and he didn't take that too kindly. He asked me for my ID and told me to get up against the car and that he was going to arrest me for obstructing governmental process and inciting a riot. He handcuffed me, handcuffed the Panther, handcuffed Wanda and threw us into the police car and took us down to the 14th Precinct. In the back of the car they told my friend Wanda that if she didn't shut up - she was just running off at the mouth, calling them a bunch of names - they were going to ram the night-stick right up her. That was their behavior and when we got to the Precinct itself they talked about holding court in the Precinct. They did a search, threw us in a holding cell and kept talking ... then they had a female guard come and strip-search us and they told her she should wear gloves and make sure she washes her hands afterwards because she could catch something from touching us. It was that experience that when they let me 
out, I called my mother and father at home and told them I was going to join the BPP. Because of the police, I told them that the police convinced me of the legitimacy of the truth of what the Panthers were saying.

I didn't get arrested for anything from that point on. I never got arrested for anything trivial. But my friend Wanda, she never learned not to get arrested for talking. I was with her when she got arrested for selling Wolves tickets and murdermouthing the police. But to me it was much more serious than that. It was more serious because they had this authority and they had the badges and they had the guns and they abused their power. And it's what they say and what they do that carries more weight in a court of law than what the individual does. It was that kind of corruption that made me make the decision to join the BPP.

Q: When was that?

1969.

Q: And then you worked with the Panthers in New York?

I worked with the Panthers. I worked out of the Harlem office of the BPP, from then until I went underground in 1974.

\section{Q: Why did you go underground?}

From 1969 until 1971, before the split in the BPP, I had a section. My responsibility was for organizing and politicizing that section, selling papers, organizing the various cell units and just politically educating that community. I did everything from selling papers and handing out leaflets to drug-detox work and everything else. By 1971 when the split came down, right after the split, I became in charge of Information and Communications for the East Coast Panthers. One of my responsibilities was to hold the press conferences and release communiqués from the Black Liberation Army.

And so I became a direct threat to the establishment. They thought I had the information they needed to capture BLA members. So they subpoenaed me. But even prior to this they had done a number of articles on the fact that I was the only ranking member in the Party without a felony conviction. And since I had no felony conviction, I had a license to carry arms. And I carried arms openly in public because the law allowed you to. You could carry long arms or have a Paratrooper A-1. I had an 8mm Mauser and I had these long arms whenever we had a press conference. Or I kept it at home and walked with it, carried it back and forth to the office, in a holster on 
the street. So the media played it up like "the Panthers with guns", but they didn't bother to investigate that it was licensed. When they finally got to the point that they realized I was legal, I was then the only ranking Party member without a felony conviction.

I had done my work in the community so well that I had a lot of community support and so on that level had organized my base area and also had the political astuteness to play the media. They thought the fact that I had the diplomacy to play the media made me a political threat. Then in 1970/71 we started the "National Committee for the Defense of Political Prisoners", in response to all the arrests across the country of Panthers and BLA members. I was working with the people in prison and they put the letters that I was sending inside to the prisoners. Our political stance was very clear, we were not about reformism or anything like that. It was about revolutionary political power and how it comes to revolution, and means a qualitative change in the living conditions of the people with us, and it was not about the NAACP (National Association for the Advancement of Coloured People — oldest liberal Black civil rights organization in the US) style politics or anything like that.

The Senate Committee in the US held hearings on the kind of political literature that was going into the prisons, so that part was a threat to them also. It was basically a lot of the political work that I was doing - back and forth to the prisons - myself and Yuri Kochiyama and many others like us. And in November 1973, myself and three other people who were part of the Harriet Tubman Brigade of the BLA were arrested for trying to break some six members of the BLA out of the Tombs (pre-trial detention prison in NYC). But the arrest was premature because even though they played it up to the media like "Great Tombs Escape Fails at the Sewer", they were not able to hold us because we weren't doing anything. The only thing they could charge us with was third degree burglary on a sewer, which was laughed out of court. And they were very angry.

Outside the legitimate system, the Police Department put a $\$ 10,000$ contract on me that I wasn't supposed to be captured. I had got into the position to be killed on sight. That was outside the normal system. And inside it, I got a subpoena by the Federal government to the Grand Juryabout 11 other people and me. But the difference with my subpoena was that if I showed up at the Grand Jury I couldn't take the Fifth Amendment and therefore for any question that I refused to answer I was facing felony contempt which carried a prison sentence. 
So we discussed it, myself and Nuh (Nuh Washington-now one of the New York Three) and some other people and we decided that I shouldn't go before the Grand Jury in April 1974, that I should go underground. And at that point I went underground with the Amistad Collective of the Black Liberation Army.

Q: In order to end the chronology, when did you get captured?

I was the unit coordinator of the Amistad Collective. So, basically I was the only female co-ordinator in a BLA unit. We were captured in a shootout in Norfolk, Virginia, on January 25, 1975. One of my co-defendants, Komposi Amistad, was killed and another one was shot in the face. For the first 30 days we were facing the electric chair for felony murder. The only reason we got out from the electric chair is that the federal government and the Supreme Court abolished the death penalty in Virginia at that time, saying it was unconstitutional. So we didn't have to go to trial facing the death penalty.

But the state of Virginia asked for 900 years on the paratrooper A-1 I told you about. They didn't care that I had a federal license. It was a one day trial, my bail was set at one million dollars on each count-we had five counts, which came to five million dollars.

They told them not to touch the bail issue, they picked the jury, they had the trial and they sentenced us all in one day and took us off to prison in one day. When they had the trial they threw me out of court before they started the trial. So I understand well Mumia not being in court during his trial, because I was not in court either.

I was in a cell in the back and it was cold and it had a loud-speaker, but I didn't hear a thing, because it was nothing but static. But they brought me back in court for the sentencing phase and I was given 40 years. The jury wanted to run the time concurrently-I got 10,10, and 20-because it was the minimum on all the charges. And the judge told them they couldn't do it, it was not up to them to determine how high it ran on the term on what I got and he ran it consecutive, and he told me I had to do every day of it. I told him, his momma was going to do it. (laughs) They sent us off to prison that night.

We both went together because they sent me to the penitentiary for men where my co-defendant was, and then I was taken by caravan to the women's institution in Richmond, Virginia, and spent the next 21 days in 
maximum security segregation, because they didn't want me on the outside where the other population was.

\section{Q: How did you get out of segregation?}

According to their own rules the only reason why you are supposed to be on maximum security segregation is when you violate one of their rules. So, I hadn't violated a rule, So, when they took me down there I asked them why I was down there and they said because they didn't have an empty room in the quarantine hall. And I asked them for a manual of their rules. I read it all and I told them, if that's the case, in 21 days then you don't have to worry about the room in the quarantine. Just that either I'll be out of maximum security segregation or you'll be in court. And so on the 19th day they sent this correctional officer down there who said that she would accept me on her hall. She asked me what my intentions were while I was in prison and I told her that my intention was to do two years and leave. (laughs).

And she said they were concerned about me organizing in prison recruiting for the BLA, and I told them I had no intentions to recruit because I don't really believe in recruiting. I believe if a person is going to do anything they need to make the decision based on their own conditions. If you have to recruit them, they haven't made a decision on their own and if they don't make it on their own they're susceptible to back out and say somebody forced them to do things and stuff like that. But if they make a conscious decision on their own that they want to be involved in something then they have nobody to blame for anything that happens.

So, I told her I had no intention of recruiting. And she said then that she didn't have any problems with me being in her hall. And so on the 21 st day they moved me to the building where this correctional officer was, but I wasn't allowed to go out into general population without handcuffs on and an armed guard with me. I wasn't allowed to go to school. I wasn't allowed to work in the kitchen or in the laundry or any other place where the women were working because they said I was a security risk. So, the only place I could be was in the hall, on the tier, in the cottage where I was housed. For everything you had to be right there at that complex.

After the first year I had to do a psychological evaluation, so that they could determine how they should handle you. The psychologist that I had to see decided that I didn't have to do all those little stupid tests, putting blocks together, etc. He asked a bunch of questions and then he said that he understood my political "beliefs"; at least how determined I was and stuff 
like that. And then he wrote this paper saying that I believed wholeheartedly in the movement and that I was adamant about that, but I would not be a disciplinary problem if they called me by my Islamic name and dealt with me in a respectful manner and then he called me "paranoid" (laughs) - that I believed that people were out to get me. But he did say that I had no need for rehabilitation - rehabilitate from what, anyway. So he told them that they had to call me by my Islamic name or Ms. Bukhari and there will be no problems. But if they tried to deal with me in any other manner, then they did have a problem with me. And that was the psychological evaluation.

Anyway, after almost two years exactly, I escaped. It was New Year's Eve, 1976. And the escape was really for two reasons. First, I just believed as a prisoner of war that a prisoner of war's responsibility is to escape. So, from the very beginning we took the position that we were prisoners of war, and at the time of our capture we were soldiers in the Black Liberation Army. We gave a name, rank and serial number only and invoked that the court had no jurisdiction to try us. Therefore, on that premise alone, the prisons had no jurisdiction over us and it is our responsibility as prisoners of war to escape - on that level I escaped. That was one of the reasons.

The other reason-one of the reasons why I was going South in the first place prior to the capture - was because I had medical problems and I needed surgery. At the time of the capture I made known to them that I needed to have surgery. They kept telling me that when I went over to the state custody it would be handled then. When I got to the prison they told me - after the examination - that I had fibroids the size of oranges or grapefruits in my uterus and asked me how much time I had. I told them I had 40 years. They then told me to come back in 10 years. I filed suit. The court said that it was just a difference of opinion between me and the doctor about how the medical treatment should be handled. I had asked to be able to pay for my own medical care, to have a doctor from the outside, etc. And they said no.

The month before my escape I started hemorrhaging so badly that at the time of my escape I was wearing three big sanitary napkins. And I would have to change them every two hours. I was having my menstrual cycle for two weeks at the time, every other week. I was just bleeding horrendously. That day, when I made the decision that I couldn't wait any longer to get medical care I was standing up in the middle of the floor in the unit where I was housed and all of a sudden-I mean nothing special happened - I just started hemorrhaging from the vagina. And I went to the clinic hall in the 
institution and they gave me Urgatrade, that was a medication to control the bleeding and told me to go and put my feet up. That was the extent of it - there was no recommendation to take me to a doctor, to the hospital or anything. I just felt that they were not concerned about my health at all.

The doctor at the institution was not qualified to deal with women. And he had been so bad that in once case, for example, he had diagnosed just a sore throat when a woman had cancer. This other woman had one ovary left and he told her she had tumors on her right ovary - she didn't have any right ovary. There was no way that you could have faith in the competency of this doctor. So, when they told me about this Urgatrade for the control of the bleeding and go and put my feet up, I decided that I had to make arrangements to take care of my own medical care.

Those of us who were in the BLA and who were incarcerated, we had a secure communication channel, so that we were still involved in what we called consolidation, organizing, structuring and stuff like that. I was in charge of Area 2 of the consolidation work in the unit and for the country. And as being in charge of Area 2, I was responsible for all the consolidation work in that area around BLA and BPP members and outside, building the whole network in that area. My second was Mark Holder who was in prison at Marion, and he was responsible for that area. So, between the two of us we had the whole Southern regional area of the East Coast in terms of our organizing efforts. Even while we were in prison, mind you...

Part of the CC, the Central Committee of the BLA, were on the streets. There were also members of the $\mathrm{CC}$ who were in prison and some were underground.

When I made the decision to escape I notified through secure channels the Central Committee that I was making a move. I notified my area coordinator and I notified the people in the area who needed to know that I was not going to be where they thought I was going to be. The night of the actual escape, we left and we made contact with the underground, and I was out roughly two months. I was captured on February 27, 1977, and returned to prison in Virginia and went to trial where I was my own attorney at this point.

During the course of the trial I raised the issue of inadequate medical care and I pleaded not guilty for reason of "duress and necessity" - that in order to save my own life I had to escape because of the medical conditions. That was also a way of raising the lack of adequate medical care for the women in the prison itself. The jury was very sympathetic and in the town a 
lot of the correctional officers and the head nurse for the correctional facility were very sympathetic because they knew this man was not qualified; that people in the town where the prison was located would not use him for anything. The only place he could practise was in the women's institution, because nobody would allow him to practise on them. So during the course of the trial this was brought out.

By the time the trial was over, the judge had to threaten the jury with contempt charges if they didn't find me guilty, because he said escape is like murder. And so they found me guilty of escape and they sentenced me to the minimum time which was one year. I was already doing 40 years, so one year didn't make a difference. And the jury stood outside the courtroom and apologized when I was going out ... (laughs). The upshot of it was that I was given a choice at that point about doctors - they picked three doctors outside who were not part of the prison system. And they took me to a hospital in Richmond, Virginia, and I picked a woman doctor and we talked about it and they did the examination. By this time it was two years after going into prison, my condition had worsened to the point where they said there were strings all across that had pulled my uterus, the tubes and the ovaries all together. And Wanda said - my doctor's name was Wanda too - that she would do everything possible to save something, but it would be a major piece of surgery. The upshot was that I ended up having a hysterectomy and that I have only one ovary left - and it's because of the malpractice of that doctor.

I suffered severe post-partum [sic] depression. For whole year I was out of it. I was still in maximum security segregation for the escape. I spent three years and seven months in maximum security segregation - that was the longest time anyone ever did for escape; before that the maximum for escape was six months in maximum security segregation. I had to go to court to come out of it and the court ordered me out of it at the end of the three years and seven months. They had to phase me out. But during the course of the trial the Warden said that I was a threat to the security of the free world if they released me from maximum security segregation. For a minute there I thought I was Russian (laughs)...

Anyway, I came out of maximum security segregation in 1981. After I came out of maximum security segregation we founded a little organization in prisons called "Mothers Inside Loving Kids" for people with a long time, to try to bridge that gap between the children and so that they can keep their 
family and that continuity with their children going. And then I made parole in 1983, and in August 1983 I was already free.

\section{Q: Did they give you conditions for parole?}

Yeah. I wasn't supposed to associate with anybody-I wasn't supposed to associate with folks. I wasn't supposed to ever have a gun in my hands again. I wasn't supposed to associate with any BLA or Panthers or anything like that. They asked me questions like: "Do you believe in violence or would you do what you did again?" And I told them that based on the conditions - no right-thinking person believes in violence for the sake of violence. But there are certain instances when you have no alternative, when you have exhausted everything else - then you have to resort to violence. And then they asked me: "Would I deal with things the same way again?" And I told them, no, I wouldn't do it particularly that way, because one of the things that is very clear is that we haven't done the necessary education and organizational work in the streets in order to deal with a movement in the ways that we moved then. We were young, we were idealistic and we were impatient.

We have to build a foundation. And we have to organize not just 30,000 people. This country has almost 300 million people in it. And a lot of people in the rural areas, and even in some of the major cities and in the suburbs, don't even know anything is happening because they are not exposed to the conditions - they just don't know about it. It's like when we talk about Mumia's situation — people have never even heard his name — and we are talking about a major situation.

So, the educational phase has to be so that when you move from one level to the next in the struggle, that it is understood that the people know what we are doing. And you lay the foundation to the point where you are not leading the people to a slaughter. And they talked about not being around people who were in the BLA and the BPP and convicted felons. And I told them that it isn't possible to live in the Black community and not be around convicted felons. To say that I won't do that I'd be lying to you.

And the other part is that these people of the BPP and the BLA are not just comrades, they are my family. And to tell me that I cannot associate with my family is something I will not accept. So I told them if you give me parole be clear about the fact that I am going to associate with my family. (laughs) And I did from day one when I was walking out of the prison. I was shocked - everyone was shocked - that I made parole. (laughs) The 
consistence was that the state of Virginia just wanted to get rid of me because it was costing them too much money lately.

The only times I did a law suit against them was when they pushed me to the point where I had no other choice but to file a suit against them. At the last when I left the prison in Virginia they had just written the first infraction ticket that I had since my escape. I was on work release and they had written the ticket because I went outside on the ground of the place where I worked at to sit down to eat lunch on the bench. And the woman who was in charge of the house, the workpolice, wrote the ticket - she was already crazy about the fact that I was a Muslim and she was a Christian and she thought that everybody in the house should be Christian.

And I didn't eat pork, and how could you be Black in the South without eating pork? She was really ridiculous with "this is my house" and this is a prison. But when she gave me the ticket, she confined me to the house, and the only thing I could come out for were meals. I didn't mind because at this point I had already made parole, I was just waiting for the date. But at the same time I didn't like that she had denied me religious freedom.

And I filed a law suit —I told her the next time she will talk to me, talk to my lawyer. I made parole and came home and the suit was still pending. Then I got a call from the lawyer to tell me that they had settled; they had fired her, they had settled the lawsuit and I hadn't even asked for damages ... I just wanted them to tell her that this was not her house and she couldn't run it as if it were her house and that she couldn't dictate what religion people could be ... I just wanted to tell her that. Because other women were scared to say anything because she was threatening to take their rights and privileges and they were not ready to deal with that. And I just didn't think that these people should get away with running their own little prisons.

Anyway, I didn't mean for her to get fired, because she was the only Black woman in that position. But she got herself into a position that there was nothing to do but to deal with it. And anyway, they gave me money damages and fired her.

Q: Can you talk about how it was to be the only woman unit leader underground?

(laughs) Sexism is, regardless of how political you are-in the United States sexism is part of the culture of the US and this is a sexist society.

In the Black Liberation movement sexism is a strong factor not only because of the sexist society in America, but because of the African culture 
itself, sexism is there. And it's there in the black culture, because of the denial of their manhood in the deculturation and acculturation that came with slavery and everything else. When the Black Power movement came into being in the 1960s and even through the Garveyites (Marcus GarveyBlack nationalist leader in the 1920s and 1930s with a strong slogan "Back to Africa"), the Garvey movement and the Nation of Islam and all other [movements] prior to that, there was a search for their manhood. You know, "Rise up you mighty Black men", Garvey said, or in the BPP the slogan was "Stand up to be Men" and so forth. So, in the Black Power movement and the cultural nationalist movement they were really blatant by saying that the place of women was in the kitchen or on their backs and having children for building the Nation and so on.

One of the things that had developed in the Panther Party and in the BLA - for us, the BLA came out of the BPP because no Party member was allowed to join any armed force other than the Black Liberation Army-was the whole machismo thing. But at the same time there was an organizational position that was anti-sexist. But the individuals themselves still had a lot of sexism within. The Party only existed for about seven years ... there was never time. You had a cultural thing that never did have time to be dealt with.

So all the "leaders" [were men], even though Kathleen Cleaver was on the Central Committee, she was just there, a figure-head mostly on the CC. She was Eldridge Cleaver's wife. So her role was not as a Communications Secretary in the sense that she was viable and working ahead, having an independent voice. Her role was that of - since she was married to Eldridge Cleaver and he was Minister of Information, the Communication Secretary. And women were still viewed more or less as secretaries. There were a few of us on the political front and at political stands and doing the same work. We were basically doing the same work in the BPP. There were a few of us who not only would do the same work, but [also] would not accept the sexism.

And in the years when I joined the party in 1969, one of the things I tried to make clear was that I did not come into the Party to become somebody's sexual toy. If I wanted to do that I could do it outside of the BPP. Also, I was in my second year at college when I joined the Party - I had already made determinations. I was raised in a family of six brothers and endless uncles ... and my mother was very strong. So there was always that leadership position. 
And when I made the determination that I was going underground, it was a determination that was based on knowing that this was the next step, this is what I wanted to do. And I had the experience of the collectives that I worked with. First it was the "Harriet Tubman Brigade"- their sole responsibility was to liberate POWs, and then it was the "Wretched of the Earth" - and we still wanted the liberation of the POWs. We saw ourselves as a collective in the sense of a collective. There were no real unit coordinators in those years.

By the time the Amistad Collective came together we decided that we wanted to organize it. We wanted responsibilities and discipline whereas a lot of other units did not have that organization. We wanted to set a pattern. We had elections based on qualifications. Qualifications and not sexuality decided who got what position. We had political education classes and we had everything - we even had " $r$ and $r$ " (rest and relaxation) because we found it was necessary that you had time to rest and recuperate.

Having the responsibility of a unit coordinator was more like keeping it all together and trying to make sure that decisions were not made on an emotional basis, that we looked at everything objectively in making those decisions. And making sure that there was a distribution of the work that didn't see the women in the cell doing the "female" work and being seen as sex objects in the cells. That didn't develop so we were able to maintain a position in our cell that we were comrades. We were comrades, we respected each other's individuality and each other's capabilities and we had the discipline that we didn't violate [the] "no drug" rule and not being intoxicated while carrying out our business and stuff like that. That was a very bad part of the movement, in the underground also, that developed in this country.

We had analyzed these things prior to us forming a cell. I think, that's one of the things that came with being a female unit coordinator-it's because women have a practical, a more practical approach to things than men do. (laughs). And that's what I think made our cell different. Even though I was captured and my co-defendant was captured and the other unit member was killed - our unit was made up of 8 people - no one else ever got captured who was in our unit. And the person who talked, who allowed us to be captured, was eventually dealt with, so the person was incapable to put anybody else in the position to be captured. You know, my co-defendant was captured and a woman was killed and I was captured, but 5 other people survived it and were capable of moving. 
And even though I didn't particularly like being in prison, we were able to do work. And during the course of the trial, we were able to educate the community. The community was the support network that we had, and even when it came down to the escapes and everything else that happened in Virginia during that time, the people were there because the unit was able to continue to do the work and put the thing together.

\section{Q: What happened to your co-defendant?}

He's out. He's in Chicago. Yeah, after I got out first, the work to get him out was a thing that we continued. I carried it on, because one of the things I told people is that I was out, but as long as he was in, I really wasn't out yet, you know. And that's the kind of cohesiveness that we maintained. Because in a lot of other cases people who were co-defendants came out and they went on about their business and forgot about their co-defendants, the people that went in with them, and I think on that end our unit set a very good example, that we didn't just walk away from the situation.

Q: And how was it for you-you already had your child before you went underground?

Yes, she was four years old when I went underground. Her father was killed during the split in the party. There were two casualties directly involved in the split. That was Robert Webb and Sam Napier on the East Coast, on the New York side of the split. Robert Webb, who is my daughter's father, had been a bodyguard to Huey Newton. And when the split went down, because he surfaced - he had been underground - he was a liability for them. He was ordered assassinated by crews from that end.

In retaliation, people from the outside assassinated [Sam Napier]. The fratricide was the most ... the police just sat back and laughed; their thing was they didn't have to get Panthers, the Panthers kill each other. That was a very crucial time for a lot of us. And when we look back at it - Sam was a loss to the movement itself because he was the circulation manager of the paper. And he lived and died for the paper. And Robert was a loss-just personally he was a loss, because of our relationship, but politically he was a loss, because he knew how to put together an apparatus. He had been in the armed forces of the US, he had come out and he was working for the liberation of our people. He had the information and the connections in order to do it; and he had the security mind - he was Deputy Field Marshal in the BPP. Anyway, at the time just before the split, my mother had taken custody 
of my daughter. I let her go and stay with my mother. And when Robert came back, we had intentions at that point to go back from the underground to get Wanda, my daughter - I named her Wanda too (laughs) - and to bring her back to stay with us and then he got killed, so it was very appropriate that she stayed with my mother. So, she stayed there and I would go and see her.

Robert was dead and I was in a very insecure position. By the time 1974 came around I already had the $\$ 10,000$ contract on me, I had the Grand Jury subpoena and I had been busted in November 1973 for the other things. So I called my mother up and I told her that I wanted her to keep my daughter. And I signed guardianship over to her. One of the things the state was trying to do was to take Panther children away from their parents because they were unfit parents, etc. I didn't want to take a chance, so I signed legal guardianship over to my mother. And I made arrangements for her schooling and everything else, and I went underground.

When I got captured, I could still see her and I had a lot of dealings with her schooling, etc. But even at that point, when the state found out about her they tried to take her, at one point just tried to kidnap her and use her for leverage against me to make me talk while I was in prison. In a lot of cases I would just call and make sure that my mother didn't let her go with strangers or someone. One time this woman came by the house and told my mother that she will bring toys for Wanda, she will come and visit and stuff like that, told my mother that she was one of my best friends, and I had told her that Wanda could come spend the weekend with her. And it just so happened that that particular weekend I called home and Momma told me about it, and I told her that I had never heard that woman's name before in my life. It was incidents like these that made us decide that she could go nowhere by herself, that she had to be taken to school and be picked up from school, and she couldn't be allowed to just have a normal life really, because they were at the point where they were using children to get information from the parents. So it was very hard to do time in prison knowing that my daughter was the target for a whole lot of things.

Q: Did she understand what was happening?

She never understood. On a lot of levels she was angry because she thought my being in prison was an abandonment of her. And then she never really understood why she had to be kept under such strict surveillance or control. And even now, I tell her now it hasn't really changed. I mean, I will 
get messages where someone has seen her here or doing this. There is no place that she can go that people don't know that she is my daughter, and so she has to watch herself very carefully about what she does and where she is and stuff like that.

Q: When we first started learning about the Black Panther Party and the BLA, the only woman's name that was mentioned was Assata and no one else. Why is that?

That's because of the media stuff. (laughs) I think the reason why you hear so much about Assata is basically because in 1973 with the shoot-out and everything that happened, the publicity was very high. So the media when they were looking for her, they called her the "soul of the BLA" and stuff like that. It was a lot of media hype and people have a tendency to deal with the media....

You know, she has survived a lot, she has learned a lot and she has studied and she has developed. And I think on that end too, I have a real problem with the fact that people deal with Assata and there are a lot of other people out there in exile that no one ever mentions.

And then you have a bunch of them in various places that nobody knows their names. And that really works with me, because we have a tendency to build superstars and the superstars get the play. And the soldiers in the rank and file and the workhorses, whose names were never known, they languish on their own. That is not the way you build movements, if you don't support the people in your movements who made the sacrifices then what incentive is there to anybody else to get involved. I have a real problem with that.

You know the names of Dhoruba Bin-Wahad, or Geronimo Ji-Jaga Pratt and the New York Three, but all the other ones who are languishing in the prisons sit there with no attorneys, no nothing and no one knows their names. You can mention their names, and it goes in one ear and out the other. A lot of times they have no commissary, they don't get visits, not even from their families do they get visits. But the families that weren't involved in the struggles that they're in prison for, they didn't make the commitments. But the people who were involved in those struggles with them, they don't even remember the names anymore.

Do you see anyone out there right now who is trying to rebuild the contacts with those comrades? It seems there are so many who need to come out just on the case that they've been involved in the struggle. 
Well, that's one of the reasons why we do the "New York Three Freedom Campaign Newsletter", we mention those people every time we get information about them, where they are and their cases, what's happening with them, we try to bring it up and build networking for different struggles around different political prisoners. We try and educate the people to get involved, educate them about the rank and file. And we try not to get involved with the personality cult, and deal with the whole issue of support for political prisoners rather than support for an individual political prisoner.

And even dealing with the brothers inside right now-because it's predominantly brothers who are inside, except for the MOVE prisoners and white anti-imperialists, there are more brothers; in the Black movement there are basically men who were involved at that time, especially Panthers and BLA members - to cross those boundaries and deal with the whole issue of political prisoners. They are pushing that now, too, that they went into prison as members of organizations and that they should be dealt with as members of organizations rather than as individuals.

There is a lot of work that has to be done - attorneys have to be found and our responsibility to ourselves is in building that foundation, because all of that is building foundations.

When you get involved in movements there should be a legal defense fund set up consistently and be there. So when a bust goes down, there is an attorney available for the incarcerated comrade. There should be no question about having to raise defense money. It should be there. By the same token there should be a mechanism to liberate political prisoners. So, that if there is nothing to be won through the courts, there is an alternative already in place.

And for those that have done their time, there should be a fund or something set up for them. I know after eight years and eight months there was a lot of psychological damage done to me personally in the time that I spent in prison. There has to be a mechanism set up so you have time to cool out and deprogram. Because that's what time in prison is-it's a time of programming. And so you have to be de-programmed. And after almost nine years, it happened to me then ... and those people who have done 15 and 17 and 20 or more years, they need it much more than I did-you know, to train them for things. And we don't have those mechanisms in place.

So when I talk about the foundations that we need to build for the struggle in this country, we talk about the basic, elementary foundations to fill a 
military apparatus and a political struggle. On the political level, we need to have our own communication centers, so we don't have to keep worrying and wondering about how we get information printed or how we are going to get this done or that done. Right now we should have the people with the necessary skills to put information out from the radio and television. And we have not pulled that together.

Q: This foundation, do you see it coming from people like yourself and people with a history in the BPP, or do you think there is that whole new generation that starts that on their own, or does the Nation of Islam do it? Who does it right now?

I don't see it coming from the Nation of Islam. I don't see it coming from any organized formation that is in existence at this point. Because there is a whole new level of thinking, a kind of way of thinking, that has to be developed. I think there are people within all those structures who have the innovative ideas and who have the foresight and who are capable of putting things together that are necessary and do it. But the question is whether or not they really know what they want.

There are a lot of times when we get thrown back in our community. In the years between elections our people see how bad the situation is and they get disenchanted with the elections and there comes along somebody saying all you have to do is to change the administration and things will be better. So they fall back into the same thing. Or you start off with leaders who are strong and audacious and they're revolutionary or they mouth revolutionary slogans and then they find that somebody offers them a piece of the pie and then they dilute their message. Like Sister Souljah recently, when she was busy talking about the need for a black army and so on, then Bill Clinton attacked her about her statement about white people, that she said black people should have a week of killing white people. And her first thing was that she never had a gun, that she never advocated violence. Her whole spiel watered down to the point that we should build our own independent political party and with a technological approach to the situation.

So, even though I am not equating her with the revolutionary leaders, I am saying at that point where you have a voice and once you get attacked or anything like that or you get offered an entree into areas where you maintain your position and you can make a difference in what's happening, you find out it was all about "this is the best for me at this point" and the amount of dollars, and it becomes different. I think we have a history of that. We have 
history of - when I made the door open for me, I am going through the door and then you forget about the persons on the other side.

So, I really think that this new movement is going to be a mixture of people from the old school whose minds are open enough to recognize that they are not the end, that people do not have to come to them before they can move forward. They don't have the absolute answer. Because some people who were in the Party think that if it isn't done the way the party was doing it, then it ain't rational. But it ain't true. The Party made a lot of mistakes too.

A lot of us inside talked about how there was a need to find new blood. And if we don't find that new blood and learn from our mistakes and build on them and move forward, then there is no hope for the struggle in this country. And if we continue to try to hold on to it and say: this is my struggle and nobody else can determine how and in which direction it goes, and you can't do this without permission from me or this is my territory and you can't walk on my territory. With that game turf mentality we are defeating our own purpose. I think, one of the things we have to do is to consolidate a lot of these organizations and we haven't done this because egos are in the way.

Egos are a very, very large part of why we have such fragmentation in this movement and we are now moving apart, not moving further. And if you look at the heads of these organizations - they are all men and they splinter off from each other and form little groups with about 30 people in them and they speak about the same constituency. We have to get past that.

What really gets me is that I hear the people saying that people are ready for this and people are ready for that and the same people who are ready for this and ready for that are the same people that they have been speaking to all the time and they haven't educated anyone else. When you go outside a certain sector-you can't even say all of Harlem knows what is going on. Just those people at that rally, or just those who listen to WLIB [NYC radio station] or just those people who call in might be ready. And they might be ready just to talk. And they are ready to do anything concrete. And then they assume just by listening to those few people that the masses are ready for armed struggle, which is not true. Because when you go out to the community, when I go to my mother's house in Richmond Hill which is right here in Queens, I know they are not ready. But they travel in these little groups, call these little demonstrations and these people come and they think that they are ready for armed struggle - it's not true. 
A lot of these people would not even know-if armed struggle broke out today-where would they go, how should you deal with treating the wounded, how would you deal with keeping the police from busting down the doors.

So, what you need to do is make those people find a way to take victory from defeat. To turn it around and let people know that you don't have to be a super-hero to be involved in the movement. But everyone wants people to believe that they're such strong revolutionaries, that they never feel pain, they never cry, they never want to chuck it all and want to go up to the mountains and read a book or something. But it's not true.

Jalil will tell you, with this New York Three case, I have been out of prison since 1983 and I have been on this case ever since, and on other cases and working on this and that. And sometimes I am going to say, I need a break, I am not going to do another day's work on this. And I say that to them and I'm gone. And now, when I say that to them, they leave me alone for a couple of weeks and then they call back and say "are you OK now?". (laughs) Because you are human, you need to do these things in order to continue to be strong enough to handle the struggle. But we want people to believe that we are superhuman. We are not like everyone else ... but we are. And we have to recognize that ourselves. And we need recharging. So, if I know that I am coming to the end of my rope, then I can take those precautions, so that I don't fall a victim to the things that are out there.

\section{Q: Is it really true that there has been no BLA since the 1980s?}

Not actually since, I would say, 1977/78. And what makes it so bad is that the government knew that. The government knew at that point that there was no political BLA happening out there, whose reason for being there was strictly to wage political and armed struggle in this country, where it was basically the military apparatus of the BPP.

I think at some [time] when you are going to the point where you recognize that in order to build a new movement that you have to expose the mistakes of the prior one, so that you don't make those same mistakes again, that when you get to that point then we will be ready to move forward again.

Q: What happened to the women, I mean the other women, who were not under so much repression. Did they go back? 
A lot of them got involved in community programs, community-based work. A lot of us are in touch with each other when we do stuff around the different cases, etc. The women do the majority of that work from one end of the country to the other. Women are raising the children and making sure that they get the education, taking care of the families of the political prisoners, just surviving themselves, because they have been the victims of a lot of these conditions. And now they are educating the youth - in the schools, colleges, universities. So they are continuing the work through the community organizations, like homeless shelters, children's programs, etc. And when we move from one point to the other we are in touch. And we talk about the women getting together and doing what needs to be done. (laughs) We are starting to write books, we are doing more political speaking.

Q: It reminds me of a visit by a women comrade from the Tupamaros who came to the FRG in April, who described a similar development in Uruguay where the women are doing the community work and the men are mostly involved in the strategy discussions.

Because the real work is done by the women on a lot of occasions. The whole theory thing and sitting back and doing the armchair theory endthat ain't giving anything to the children, it's not educating them, that ain't keeping them out of prison, it's not doing that. And we have to keep our feet on the ground and keep moving and keep them alive while we build the movement.

Q: You said that you are involved with Islam. Does it interfere with your work at all?

I became a Muslim before I went into prison. I became a Muslim in 1971. It is in the Quran that it is incumbent upon a Muslim to wage a struggle against tyranny and oppression wherever it may be found. That gave me the license to be a revolutionary and a Muslim at the same time.

And I take it to the extreme, to the extreme I think it is meant to be taken, that a true Muslim will not sit idly by and allow tyranny and oppression in whatever form to happen without waging struggle against it. So, I see no contradiction between being Muslim and a revolutionary. I see a contradiction in the way that Islam is practised in the world. I remember that when I was captured in Virginia, the Islamic community sent a representative to see me and told me that they would not support me as long as I did not veer my 
case from my co-defendant's case. There was something totally wrong with them taking a position like that.

I know I came in a lot of conflict with people who thought because I was a woman and a Muslim that I shouldn't do this and shouldn't do that. And when someone is asking about my political beliefs and affiliations and how it's not according to the Quran, I refer right back to Sura 23.

Q: Well, I think in Europe we hear very little about the revolutionary writings in the Quran.

Well, that's because they don't want to do anything. The Muslims even here-for them it's a way of separating themselves from society without taking on society. So they become different and say they are not governed by the laws, etc.

The worst thing that has ever happened is having four wives. It isn't based on Islam, Islam is explained by men in the religion. And the women don't read the Quran for themselves, so they are victimized by Islam. So, they don't understand that the men cannot have four wives without the permission of the woman, you know. (laughs) So, if she doesn't go along with it, it ain't happening. That in order to have four wives, they have to be taken care of economically, psychologically, physically and spiritually. And I mean, I don't know too many men who can deal with more than one woman and take care of her. (laughs) And that's the case, and then there shouldn't be four wives happening anyway. But these men get the women, put them on welfare and call themselves Muslims they have no understanding for themselves for they have never read the Quran.

\section{Q: Do you want to add something to the interview?}

Yes, I just want to reiterate the fact that everyone of us has weaknesses. So, the weakness that people fell into after the "leadership of the movement" went to prison or were wiped out - what you had left was a lot of people who could not function without organization. The organizations were destroyed, they were out there by themselves and then they got caught up in a lot of negative stuff.

Q: Actually, I have one more question. Do you feel you can work at all with what's left of the white feminist movement or the white women's movement? Is there any kind of working relationship or do you just say they don't have a revolutionary program and so you can't work with them? 
It depends. I think in the beginning of the feminist movement in this country it was fairly progressive. Now the feminist movement in this country has just as many right wing elements as you have revolutionary elements. As a matter of fact, I would say the right wing elements outnumber the revolutionary elements in the feminist movement in the US.

And not just in the white feminist movement, but in the Black/Third World feminist movement also. Sometimes I think that they equate their individual issues with revolutionary struggle, which is not one and the same.

And even with the lesbian and gay community's struggle in this countrya lot of them are just as conservative as their counterparts in the heterosexual community. And they don't understand that the issue of sexuality itself is not a revolutionary issue. A lot of people don't see the difference. They don't see that that is not a revolutionary issue and that it is not an issue that you can impose and make it an issue of the Black Liberation movement.

When I address the issue of oppression based on sexuality, I make clear that oppression in and of itself, regardless of what reason you oppress people, is wrong. So, to oppress a person because of their sexuality, that in itself is something that we can't contend ... with.

Now, once you get past that, then it's your personal choice. And I think that it doesn't fall on the level of racism or class oppression.

And then dealing with the feminist movement they have the question of reproductive rights or pro-choice, choice, and no choice. That is a movement by itself. On the Left, we take the position that a person's body is their own; that there is a choice that they should make about themselves.

But when you get to the big question, you got just as many cops, female cops, and female judges, and female prosecuting attorneys and oppressive forces who are pro-choice and anything else. So, being pro-choice is not a revolutionary position. And so you can't continue to equate and allow ourselves to be put in a position that we get dictated to by people who are in one issue forces.

Safiya Bukhari (formerly known as Bernice Jones) was a dedicated community activist and former political prisoner. She joined the Black Panther Party in November, 1969. She and other activists formed the "National Committee to Defend Political Prisoners". Even as a member 
of the BPP, Safiya became a citizen of the Republic of New Afrika and took on Islam as her religion and found great strength in the spirituality it embodied.

In 1974, Safiya was subpoenaed to testify before a grand jury in a case against the Black Liberation Army. She refused to testify and went underground, joining the ranks of the BLA. In January 1975, she was captured, convicted and sentenced to 40 years. On December 21, 1976, Safiya escaped from the Virginia Correctional Centre for Women. She was re-captured on February 21, 1977 and returned to prison. On August 22, 1983, she made parole. Following her release, Safiya worked on the cases of political prisoners, including the New York Three and Mumia Abu-Jamal. By 1998, she along with others founded the "Jericho Amnesty Movement" to free all political prisoners. Safiya died on August 24, 2003 at age 53.

Safiya's exemplary life and spirit will be a shining light for us for decades to come.

\section{Safiya's work and related documents:}

- Safiya: Lioness for Liberation, by Mumia Abu-Jamal

- Tribute to Safiya on her passing, from the NYC Free Mumia AbuJamal Coalition

- Reminiscence of Safiya Bukhari from the Provisional Government, Republic of New Afrika

- Tributes from Assata Shakur, Nehanda Abiodun, Sally O'Brien, and Yuri Kochiyama

- Defending Kamau Sadiki, Safiya's last project

- Safiya Bukhari, "Coming of Age: A Black Revolutionary," Notes from a New Afrikan

- P.O.W. Journal, Book 7 (Spear \& Shield Publications, 1979). Reprinted with updates in Joy James, ed., Imprisoned Intellectuals (Rowman \& Littlefield, 2003).

- Page maintained by Jericho Amnesty Movement, San Franciso Bay Area. Updated October 12, 2003. 